José Luis Rodríguez-Sáez*

ORCID: 0000-0002-7736-9004

Valladolid, Spain

Araceli del Pozo Armentia**

ORCID: 0000-0002-0088-5609

Madrid, Spain

Alfonso Salgado Ruiz***

ORCID: 0000-0002-3534-2276

Salamanca, Spain

\title{
The Preventive Pedagogy of Saint Ludovico Pavoni
}

\section{Pedagogia prewencyjna świętego Ludwika Pavoni}

Summary: Saint Ludovico Pavoni was born in Brescia (Italy) in 1784 and died in Saiano (Brescia) in 1849. He dedicated his life to the training of young people

* Dr. José Luis Rodríguez-Sáez is an associate professor in the Department of Psychology at the University of Valladolid. Address: Facultad de Educación y Trabajo Social. Paseo de Belén, 1, 47011 Valladolid; email: joseluis.rodriguez@uva.es

** Prof. dr. Araceli del Pozo Armentia is an research professor at the Faculty of Education of the Complutense University of Madrid, in the area of Personality, Evaluation and Psychological Treatment in the degrees of Pedagogy and Social Education, and a visiting professor in the Sophia University Institute in Italy. Address: Universidad Complutense de Madrid, C/ Rector Royo Villanova 1, Ciudad Universitaria 28040 Madrid; email: apa@ucm.es

*** Prof. dr. Alfonso Salgado Ruiz is a professor of Biological Psychology and specialist in Clinical Psychology. He is currently Dean of the Faculty of Psychology and director of the 
and children through the workshops and a characteristic educational method. Priest, man of God, apostle of the world of work, pioneer of vocational training even before John Bosco, father of orphans and deaf mutes, and forerunner of the Catholic publishing house. In 1847, he founded the Congregation of the Sons of Mary Immaculate (Pavonians). In 1821, he gave rise to the Institute of San Bernabé, a 'School of Crafts', so that "the homeless and the most neglected by the parents themselves, find a free shelter and they will surely grow up educated in the honorable arts". For 30 years, Pavoni would direct this Institute by directing the educational method and the workshops (typography, forge, binding...), for the results obtained, and for prevention and treatment of situations that were, in the 19th century, true social scourges. Here, Pavoni developed his own method, being at the forefront of pedagogues of the 19th century, a method based on the love for kids, rationality, the importance of work, emulation and honour, prevention and the gospel. Even now, the Pavonian family continues to work on Pavoni's tracks.

Keywords: preventive pedagogy; Pavoni; Pavonian educational method.

Streszczenie: Św. Ludwik Pavoni urodził się w Brescii (Włochy) w 1784 roku i zmarł w Saiano (Brescia) w 1849 roku. Swoje życie poświęcił wychowaniu młodzieży i dzieci poprzez warsztaty i specyficzną metodę edukacyjną. Kapłan, człowiek Boży, apostoł świata pracy, pionier nauczania zawodowego wyprzedzający w tym obszarze Jana Bosco, ojciec sierot i głuchoniemych, założyciel katolickiego wydawnictwa. W 1847 r. założył Zgromadzenie Synów Maryi Niepokalanej (pawonianie). W 1821 r. dał początek Instytutowi Świętego Barnaby, „Szkole Rzemiosła”, tak aby „bezdomni i najbardziej zaniedbywani przez samych rodziców znaleźli schronienie i dorastali kształceni w szlachetnych sztukach". Przez 30 lat Pavoni będzie kierować tym instytutem, wskazując metody edukacyjne oraz warsztaty (typografia, kuźnia, wiązanie...), dla uzyskania pożądanych wyników oraz zapobiegania i leczenia sytuacji, które w XIX wieku stanowiły prawdziwe plagi społeczne. Tutaj Pavoni opracował własną metodę, stając na czele pedagogów w XIX wieku, metodę opartą na miłości do dzieci, racjonalności, znaczeniu pracy, naśladowaniu i honorze, zapobieganiu i Ewangelii. Również współcześnie pawonianie wykorzystują ścieżki wyznaczone przez św. Ludwika Pavoni.

Master's Degree in General Health Psychology at the Pontifical University of Salamanca. Address: Universidad Pontificia de Salamanca, C/ Compañía, 5, 37002 Salamanca; email: asalgadoru@upsa.es 
Słowa kluczowe: pedagogia prewencyjna; Pavoni; pawońska metoda edukacyjna.

The saints, in their great variety of experiences, charisms and mission, are encouraged by a deep passion for the Church and for humanity. For this reason, they have taken the world of youth seriously. They have understood that targeting young people means tending towards the edification of society and the Church. This passion for young people is also expressed in the social and charitable field. In this sense, one of the innumerable initiatives, undertaken in the field of social works, is that of saint Ludovico Pavoni, who, coming out to meet orphans and abandoned, shows the passion for this favourite portion of Jesus: the young, poor and homeless ${ }^{1}$.

The educational action of Pavoni is inscribed, historically and culturally, in an era characterised by profound political and social changes: the French Revolution (1789), the Jacobina period (1797), the Napoleonic domain with different denominations - and finally, since 1814, the Austrian domain.

The aim of this study is to investigate, through the analysis of the few documents that Pavoni wrote during his life and other writings of those who knew him and shared his charisma or studied his educational action, how the founder of the Children of Mary Immaculate (Pavonians) established his own educational method, at the forefront of the pedagogues of the 19th century; a method based on the love for youth, the rationality, the importance of work, the emulation and honour, the prevention and the Gospel.

Ludovico Pavoni, founder of the Congregation of the Sons of Mary Immaculate, can be defined as a "social saint". He did not stand out for great written works that went down in history; he did not obtain academic recognition nor was he an exceptional theologian, nor did he have the skills of a preacher or a charismatic leader to attract the crowd. His was to be a man of action; but a silent action, without ostentation. He anticipated the intuitions and experiences of Don Bosco or Father Murialdo. Additionally, seeing, in the phenomenon of youth marginality, one of the main dramas that characterise the period between the old regime and the industrialised society,

1 Fabio Ciardi, "Los jóvenes y la pedagogía de los santos", Unidad y Carismas 32 (1999): 21-27. 
he understands that the solution can only pass through the integral education of the person, providing special attention to professional training ${ }^{2}$.

Pavoni was born in a noble and rich family of Brescia, but his dignity as a noble did not separate him from being with the children of the peasants, whom he taught to read and write. Together, they learned the catechism. Always eager to help them, he was always concerned about their fate. From all that, the Lord wanted to use him, to call him, to take him out of the tranquillity that surrounded his life and to awaken in him the desire to be a priest to serve the poorest, especially the young ${ }^{3}$. Very soon, the then bishop of Brescia, Monsignor Gabrio M. Nava, examined Pavoni's good qualities and his special talent in dealing with children, especially those who did not stand out for their refinement, the less easy, the more poor (and the poor of that time were tattered, achy, smelly, unpleasant...), and asked him to be his secretary, without leaving his charity. Pavoni accepted and was encouraged by the bishop to open an oratory for poor boys ${ }^{4}$. From these events others followed: he was appointed canon of the cathedral and rector of the church of saint Bernabé. Yet neither the incense of the cathedral, nor the honours prevented that in the heart of Pavoni the tenderness of a father who felt passion for his children was being forged.

However, the oratory was not enough. Pavoni understood that it was urgent to offer a point of reference to his young people without time and space constraints. In addition, he noted that the unacceptable work environment to which young people from the low vulgar were subjected could wreck the educational work of the oratory. The young people were "unfortunate victims of the spirit of irreligiosity, of the debauchery of customs and of a depraved moral that dominates even in the most humble workshops"5; all of this provoked in the heart of Pavoni a suffering that was not lost in resignation, but caused the search for a reparative and preventive intervention. The idea was born or, rather, the "plan" that seemed to be "dictated by Heaven" (General Idea) to found the Institute of San Bernabé, which would become a new family in which the boys could grow and be lovingly welcomed, and could also

2 Aldo María Valli, La creatividad del amor. San Ludovico Pavoni (Milán: Áncora Editrice, 2016).

3 José Luis Rodríguez-Sáez, "Ludovico Pavoni: un padre para los jóvenes”, Unidad y Carismas 32 (1999): 28-30.

4 Teresio Bosco, Lodovico Pavoni per i giovani a tempo pieno (Milano: Áncora, 2002); Humberto Folena, Con manos de padre. Beato Ludovico Pavoni (Barcelona: Claret, 2003).

${ }^{5}$ Giuliano Bertoldi, L'esperienza apostólica di Lodovico Pavoni (Milano: Áncora, 1997). 
learn to perform a trade and be educated Christianly. The Institute should not be understood only as a lodging but, above all, as a place that offers a paternity relationship. It is the antidote that cures the abandonment that the young man is suffering: orphans and abandoned are picked up; shelter heals suffering and loneliness. In his memoirs, Baldini, one of Pavoni's first successors, makes this very important statement:

The true idea, the characteristic idea of the Pavoni Institute is this: that the poor and abandoned children of their closest parents and relatives will find there everything they had lost [...] it is not only about finding in the Institute bread, a dress and an education in letters and arts, but also the father and mother, the family from which misfortune had deprived them; and with the father, the mother, the family, everything that a poor person could receive and enjoy there ${ }^{6}$.

However, Pavoni did not take a single step without first contrasting and discerning with his bishop, what he thought was a breath of the Spirit. For Pavoni, obedience was nothing but the prolongation of Christ's love for his Father and for men. Later, when he arrived to found the congregation of religious dedicated to perpetuating the work he began one day, he exhorted the members of his community to practice "filial obedience", considering it as "the most beautiful ornament" of the religious community. Over time, Pavoni obtained recognition and civil approval from the Institute of San Bernabé as an education institute and later housed deaf-mute people in it. The Saiano project then started in a small town near Brescia, where Pavoni developed and expanded the Brescia structure, with the relevant adjustments. Here, Pavoni displaced artisanal agriculture, but it was the same educational system and the same recipients who benefited from this agricultural school. The idea of "art school" was something completely new for that time. Certainly, there were already welfare structures, such as orphanages for orphaned or abandoned children, popular schools (such as those founded by saint José de Calasanz in the 16th century) and study colleges and, almost at the same time as Pavoni, Father Ferrante Aporti opened the first hospice for poorer children in Cremona. However, the Institute of San Bernabé that

${ }^{6}$ Lodovico Pavoni visto da vicino - Il "Processo informativo" per la beatificazione e canonizzazione - Brescia 1908-1912, ed. Giuseppe Rossi (Milano: Congregazione dei Figli di Maria Immacolata (Pavoniani), 1995), 320.

7 Congregazione Religiosa dei Figli di Maria Immacolata - Pavoniani, La Regola di Vita. Costituzione. Direttorio (Brescia: Grafiche Pavoniane Artigianelli, 1996): 97. 
was in Brescia was the first of its kind: it was a true technical and professional school, equipped with laboratories and workshops that not only allowed young people to do internships, but also became productive centres. If we also consider the number of professional profiles (no less than eleven: typography, chalcography, printing, binding, stationery, silverware, locksmith / blacksmithing, carpentry, turning, footwear / shoe store, agriculture), we see how Pavoni put into operation what would later be professional training, which is now part of our educational system ${ }^{8}$.

What does his educational method mean to Pavoni?

Pavoni was not a pedagogue who trained at the university or wrote academic texts that influenced the pedagogical field, but was a pedagogue "graduated in the field experience", who managed to combine the alphabet of the heart with a non-welfare charity, but promotional and creative9. He put into practice an authentic educational method that is characterised by emphasising prevention.

The centrality of the Christian faith, the love for each and every person, the importance of work as an instrument of human and social promotion, the firmness of the rules within an organization that, however, is familiar, the attention paid to the personal relationship and the recourse to the arguments founded and discussed rather than to the imposition are the elements that make up a project that aims to provide young people with the essential instruments to guarantee them a balanced personality and a recognized social role, in instead of the impact with the social reality that pushes them inexorably to marginalization, with all the personal and collective costs that derive from here ${ }^{10}$.

Pavoni considered that education was to support God's project on each one and guide a boy towards the goal of a full realisation of God's design in his life. His educational method was the key to success in the difficult task of saving so many young wretches from the "shipwreck". Pavoni did not get carried away enthusiastically because of the urgency of the need and the desire to act or start improvised or random activities; it is rather one that matures its intuitions with a thoughtful reflection, carefully studying the

8 Valli, La creatividad.

9 Giovanni Battista, "Presentazione", in Il progetto educativo pavoniano (Milano: Congregazione Religiosa dei Figli di Maria Immacolata. Pavoniani. Provincia Italiana, 2010): 3-6; http://www.fassicomo.it/file_db/fassicomo.it_1297618930.PDF.

${ }^{10}$ Valli, La creatividad, 12. 
problems, confronting each other and asking for opinion from others. The path that led him to his final options was marked by some essential stages: personal reflection on the experience data (analysis, project); verification with other people (for Pavoni the obliged counsellor was his bishop - Mons. Nava); drafting of a Regulation that serves the different educational agents to be fully concordant in the educational method (the Regulation is the instrument that leads to being concordant in the action and is a guarantee of effectiveness) and evaluation of the achievements that highlight the good company results ${ }^{11}$. For Pavoni, educational action within the youth world is fully effective if it is penetrated by a family atmosphere, marked by respect for freedom and human dignity. The family spirit constitutes the cornerstone of the environment that was lived in the Institute of San Bernabé. A spirit that fed on the pedagogical wisdom of Pavoni, which recommended the education of young people with some advice such as those contained in the Primitive Constitutions (CP):

Try to understand the spirit of young people, guiding them with great insight and with Exquisite prudence, study the character and strength of the students to lead them [...] according to their abilities and the gifts they have received from God; treat them with great urbanity and sweetness, doing everything to everyone to help them on their way; believe in them the habit of working more for love than for fear; keep them as a precious and holy deposit and love them like the girls in your eyes ${ }^{12}$.

For the clarity of the educational objectives, for the concretion of the interventions implemented, for the improvement of the educator-educating interpersonal relationship, one can rightly speak of a Pavonian educational method that is presented with its own and original characteristics, and whose essential nuclei deserve to be studied and proposed to our time ${ }^{13}$.

Schematically, Gallina collects a kind of pedagogical decalogue, on which Pavoni, in fact, has built his educational action:

11 Bertoldi, L'esperienza.

12 Constituciones de la Congregación Religiosa de los Hijos de María (Brescia: Tipografía Episcopal, 1847; Milán, 1970). These constitutions are commonly known as Primitive Constitutions (CP), cf. n. 238, 259, 260, 272, 258, 257.

13 Aurelio Gallliga, "Il metodo educativo di Lodovico Pavoni", in: Il progetto educativo pavoniano (Milano: Congregazione Religiosa dei Figli di Maria Immacolata. Pavoniani. Provincia Italiana, 2010), 77-93; http://www.fassicomo.it/file_db/fassicomo.it_1297618930.PDF2010. 


\section{An educational method with flexibility and openness to change}

At the beginning of the Constitutions, which ended in December 1845, in the General Idea that introduces the text, Pavoni wrote that, for the sake of young people, you must choose "all those means of education that are appropriate according to the circumstances and places". As an example, he suggested that it would be convenient to train the boys "in mechanical arts if $[\ldots]$ they are in the cities, or in agriculture if they were in the countryside" 14 .

\section{A method that speaks to reason and the heart}

According to Rossi ${ }^{15}$, in Pavoni's letters to Guccini, one of his disciples sent to Milan to train as a teacher of deaf-mute people, he taught him how to conduct himself in each encounter with young people: "The whip for man must be the reason" 16 . He had always argued that, with severity, few go to heaven and that children should feel loved ${ }^{17}$.

As a relevant novelty, regarding its time, Pavoni rejected any coercive methodology and any recourse to physical punishment. The seriousness that inspires respect, kindness that attracts and enchants are the tools of the good educator. On this point, his thinking was very explicit and clear. Instead of resorting to the severity system, with which children are often induced to act more out of fear and hypocrisy, than out of feeling and love, Pavoni chose emulation and honour, for which everything is possible in the heart sensitive of youth.

\section{A founded method of collaboration}

The term "collaboration" never appears in Pavoni's writings, but in all his educational practice there is clearly the conviction that education is team-

14 Constituciones, n. 122.

15 Lettere di Lodovico Pavoni a Domenico Guccini, ed. Giuseppe Rossi (Milano: Congregazione dei Figli di Maria Immacolata (Pavoniani), 1984).

16 Ibidem, n. 29.

17 Giannina Facco, Lodovico Pavoni. Così si fece prossimo (Milano: Áncora, 1987). 
work. Precisely for this reason, Pavoni wanted to have regulations in his structures of service to children and young people, both in the Oratory and in the Institute, which in some way anticipate the current need for educational projects; in the introduction of the Regulations of the Institute of San Bernabé he wrote the following: "even if we were satisfied with the sentiment, we could not achieve success in the [educational] enterprise without agreeing with the method of education"18.

\section{Puerocentrism or attention to the person}

In the Pavonian educational method, the educator's first concern is to study the personality of each child to reach a deep knowledge and an interpersonal relationship: discover the character traits, intellectual abilities, emotional dynamisms, previous experiential experiences, action mystery of Providence and the grace of God, to then be able to support what is positive and correct what is wrong. The teachers and instructors of the workshops "will study well the character and strength of the students to conduct them according to their spirit; for not everyone wants to be guided in the same way, but according to their abilities and the gifts they have received from God"19.

\section{Family spirit, dominant note of the Pavonian method}

"They will love them like the girls in their eyes." ${ }^{20}$ The goodness and effectiveness of an educational method are determined, above all, by the quality of the relationship that is to be established between educator and educated, by the human climate that is determined in the environment in which both interact, in short, by the spontaneity and cordiality that permeates the entire network of relationships that are created in a coexistence.

Thus, there is no doubt that the dominant characteristic of Pavoni's educational method is a broad and deep attitude of love, inspired by the family model; attitude that is distinctively Pavonian and that traditionally has been called "family spirit". The entire Pavoni epistolary is full of rich expressions

\footnotetext{
18 Raccolta ufficiale di documenti e di memorie d'archivio, vol. I (Brescia: 1947), 43.

19 Constituciones, n. 259.

${ }^{20}$ Ibidem, n. 257.
} 
of affectionate feelings, of delicacy and of prompt attention. Just read the letters addressed to Domenico Guccini ${ }^{21}$. Additionally, in his memoirs, Father Baldini, one of Pavoni's first successors, emphasises that the characteristic idea of the Pavoni Institute is that poor and abandoned children find everything there that they had lost... not only their material and formative needs met; but also the father and mother, the family from which misfortune had deprived them ${ }^{22}$.

\section{The Christian faith, soul of all educational action}

All of Pavoni's educational action would not be understood if he had departed from a deeply Christian vision of man, of his destiny, of the religious meaning of life. In fact, he sees in religious formation "the main and most essential objective of education" ${ }^{23}$. From their rich experience of faith derive their educational principles. First, moral and Christian formation begins with religious instruction. In Pavonian educational structures, there will be "special care to effectively form the hearts of young people, to teach them with righteousness according to faith and religion" 24 . This explains the need for a timely catechesis and a gradual approach to the Bible. Furthermore, together with the religious instruction, one must concurrently proceed to the formation of a Christian conscience and a mentality of faith; thus, the animator will ensure that children and young people discover "that everything that is not of God is nothing and look at things with the light of faith".

\section{School-professional activity as an educational factor}

Ludovico Pavoni, anticipating modern ergotherapy, was aware that a professional activity that is well adapted to the subject can become an effective stimulus for the maturation and growth of the person, who, finding at work healthy and deep gratifications in addition to a medium of subsistence, sees his educational process reinforced. The profession thus becomes a means of

\footnotetext{
${ }^{21}$ Lettere di Lodovico Pavoni.

22 Lodovico Pavoni.

${ }^{23}$ Constituciones, n. 244.

${ }^{24}$ Ibidem, n. 123.
} 
formation of man and of the Christian ${ }^{25}$. In fact, Pavoni writes in his Constitutions: "The purpose that the Masters have to propose is not so much to enable their students in the arts they profess, as to educate their hearts in the love of religion and in the practice of moral virtues" ${ }^{26}$.

\section{Order, discipline, sacrifice}

The Pavonian educational method also gives a lot of weight to sacrifice and discipline, as important elements of education to balance self-control of one's own drives. It is necessary to coordinate and integrate all the vital energies of the person. In that sense, the educator "must correctly use [with the students] sweetness and strength" ${ }^{27}$.

In the Primitive Constitutions, Chapter VI claims: "See everything, hide and correct wisely, and punish little, but let the necessary punishments be healthy and effective. Be very moderate in sanctioning those defects that come from youthful vivacity, lightness and thoughtlessness; nevertheless, it is inexorable to punish the faults that originate in ill will and are sustained by an obstinacy of the heart." 28

Additionally, in Chapter VIII of the Primitive Constitutions, the instructors of the workshops are urged (but the indication would be valid for any educator), not to yield "never before [...] irrational claims [of their students] nor their caprices will allow them. Don't demand too much, but don't be weak either." ${ }^{29}$

\section{Climate of joy and jovial activity as characteristic notes of the Institute}

The climate of serenity and joy that Pavoni wanted in his Institute derive in the first place, from a style in interpersonal relationships marked by cor-

${ }^{25}$ Roberto Cantú, “'Le Scuole delle Arti’ di Lodovico Pavoni e l'instruzione professionale a Brescia", in: Lodovico Pavoni, -un fondatore e la sua città-, 2000, Atti del Convegno di studi di Brescia 27 marzo 1999.

${ }^{26}$ Constituciones, n. 254.

27 Ibidem, n. 274.

${ }^{28}$ Ibidem, n. 242.

${ }^{29}$ Ibidem, n. 258. 
diality, joy and dynamism. In this sense, Pavonians and educators in general should be trained.

In the Primitive Constitutions, the Novice Master is urged to "try to form them open and sincere, vivacious and cheerful, awake and active" ${ }^{\prime 30}$. Likewise, the local Superior is urged to ensure that the religious are of "jovial, cheerful and pleasant character. It must not allow sadness and melancholy, which are so much opposed to the spirit of our Institute." 31 When admitting young people to Pavonian life, the responsible person will have to evaluate not only moral qualities and religious motivations, but also their "docile, sincere and cheerful" character ${ }^{32}$.

It is often said that the gentleman is known at the table and in the game. In this respect, the game and the moments of recreation, in the Oratory and the Institute, were especially valuable for Pavoni. To those responsible for the educational activity Pavoni recommends to value recreation as a moment in which the boys "manifest themselves as they are" ${ }^{33}$; and, through the commitment of the game, to educate their tendencies.

\section{The law of gradualness}

As a good connoisseur of youth, Pavoni knew very well how marked the differences in character are between each child, and how relevant the transformations are that occur in students throughout human development in the life cycle, especially between adolescence and youth. In the Primitive Constitutions, he urges instructors and educators to study "well the character and strength of the students to lead them according to their spirit: well, not everyone wants to be guided in the same way. They will not demand the same from everyone, but according to their abilities and the gifts they have received from God." ${ }^{34}$ Directed to the Novice Master, but which is a general norm for any educator or teacher, Pavoni wrote: "It will demand of all goodwill, and of the beginners, above all, do not pretend anymore, that from these you cannot require prudence and judgment of the mature" ${ }^{\text {" }}$.

\footnotetext{
30 Ibidem, n. 270.

${ }^{31}$ Ibidem, n. 215.

32 Ibidem, n. 23.

33 Ibidem, n. 242.

${ }^{34}$ Ibidem, n. 259.

35 Ibidem, n. 271.
} 


\section{Conclusions}

Rediscovering the social holiness of Ludovico Pavoni leads us to discover to what extent his influence and that of people like him was decisive, thanks to which faith and the Church could survive and, even more, strengthen. Men and women who, in the light of the Gospel and with the only law of love, drew strength precisely from the tests they found and had to face ${ }^{36}$.

Among the founders of the 19th century, Pavoni does not shine for the greatness or the immensity of the initiatives, but for being a humble pioneer who meticulously opens the way that other educators of children and young people known internationally will follow later, such as Saint John Bosco and many others (in Northern Italy, Kazimierz Siemaszko in Krakow, Poland). Braido points to Ludovico Pavoni among the authors most closely related to the birth and cultivation of the "preventive system" in the educational field ${ }^{37}$. Other "educators" who address and contribute to the development of the concept of Preventivity as a pedagogical formula are: Antonio Angelo (1772-1858) and Marco Antonio Cavanis (1774-1853); Marcelino Champagnat (1789-1840); Ferrante Aporti (1791-1858); Pierre Sébastien Laurentie (1793-1876); Antonio Rosmini (1797-1855); Teresa Eustochio Verzeri (1801-1852); Pierre-Antoine Poullet (1810-1846); Felix Dopanloup (1802-1878).

In many pages of the Don Bosco's papers and letters, we can find expressions and terms used by Pavoni with similar frequency (i.e. "prevention", "educational presence", "kindness and sweetness", "family and festive atmosphere" $)^{38}$. To differentiate between saint Ludovico Pavoni's pedagogy and saint John Bosco's one is a difficult task. There are three basic elements of Don Bosco's preventive system: reason, religion, loving kindness ${ }^{39}$. These three elements, closely related to each other, constantly emerge in the style and writings of Pavoni and also constitute, as we can see throughout this study, fundamental pillars of Pavonian pedagogy. Love and reason are cri-

\footnotetext{
36 Valli, La creatividad.

${ }^{37}$ Pietro Braido, Breve Storia del "Sistema Preventivo" (Roma: Librería Ateneo Salesiano, 1993).

${ }^{38}$ Giovanni Battista Lemoyne, Memorie biografiche di Don Giovanni Bosco, vol. IV, 1904; Bertoldi, L'esperienza.

39 Eugenio Valentini, "La salesianità di Don Bosco", Rivista di pedagogía e scienze religiose 1 (1967): 3-47.
} 
teria that are repeated continuously in the educational indications of Pavoni, from the regulations of the Oratory to that of the Institute, and later in the Constitutions. Reason and love also inspire the method of correction. Instead of resorting to the severity system, with which children are often induced to act more out of fear and hypocrisy, than by feeling and love, Pavoni has chosen emulation and honour, for which everything is possible in the sensitive heart of youth. In terms of religion, Pavoni's entire educational action would not be understood if we depart from a deeply Christian vision of man, his destiny, and the religious meaning of life. In fact, Pavoni sees in religious formation "the main and most essential objective of education"40.

Thus, a fertile pedagogical knowledge capable of illuminating the hottest educational problems of our time can be found in Pavoni, and also an educational model of particular relevance that includes not only the most precious aspects of a long educational tradition, but based on principles and permanent values, that constitute the pillars on which its educational proposal is based: the Preventive System.

Due to his awareness of the importance of the press, for his attention to the world of work, the use of vocational training as an instrument of recovery and reintegration and for the inseparable union between work activity and a religious vision of life, Pavoni could be considered a precursor of the Catholic movement, that is, of that set of ideas, programmes, organisations and initiatives that will lead Italian Catholics, in different and sometimes confronted ways, to participate in the citizen's life of the country, living in an often dramatic way and lacerating the Roman question and the coexistence of the papacy with the predominance of the liberal state and an increasingly secularised society. However, it should be noted that Pavoni never acted strictly for social purposes, much less political; although his activity had consequences on the social level. Pavoni always acted for specifically religious reasons: "I knew that, forming good Christians, I automatically formed good citizens" 41 .

Pavoni did not travel alone on his educational adventure and he established close relationships with people engaged in the field of education such as Teresa E. Verzeri, founder of the Congregation of the Daughters of the Sacred Heart of Jesus. Circumstances made Pavoni know and admire the text of the Constitutions of Verzeri in the 1841 edition, being a source of

\footnotetext{
40 Constituciones, n. 244.

${ }^{41}$ Valli, La creatividad.
} 
reference for the drafting of his own Constitutions of the Congregation of the Children of Mary ${ }^{42}$.

In the vision of the problems of youth (marginality, external and internal poverty...), the first and main objective of Pavoni was always educational, and at the origin of his commitment was the need to fill an emotional void. If this perspective is not taken into account, the work undertaken by Pavoni cannot be understood. His proposals (the oratory, the institute, the workshops, the training) take forms that use different instruments and are carried out in different fields (social, technical, professional, economic), but are born from a religious and spiritual vision of human existence, a vision that always puts the person first as a creature, deserving and, at the same time, in need of love ${ }^{43}$.

Father Pavoni leaves us an educational testament that is worth keeping in mind, allowing his pedagogical intuitions to remain alive. Through the Congregation of the Sons of Mary Immaculate and her charisma such intuitions will continue to convey educational wisdom for the youth of the third millennium.

As Pope John Paul II said in the audience after his beatification:

he was able to elaborate... an educational method based on the typical means of preventive pedagogy, such as religion and reason, love and sweetness, vigilance and knowledge within family structures and intense work activity. And he managed to organize a model of education and preparation for work, which was a prelude to modern professional schools, introducing reforms that prophetically anticipated the social doctrine of the Church, expressed later in the Leon XIII's encyclical Rerum Novarum ${ }^{44}$.

In summary, with these considerations, it can be affirmed that the Pavonian charism, mainly expressed through the Pavoni Preventive System, is a valid option for the formation of good Christians and honest citizens today. Now, the following question immediately arises: Pavoni lived more than a century ago and he responded effectively to the needs of his time, but are his answers still valid? Why is it perennial?

It is necessary to be clear that Pavoni lived in a different time and place from ours, and, therefore, he was conditioned by his own context. Pavoni

42 Bertoldi, L'esperienza.

${ }^{43}$ Valli, La creatividad.

44 Juan Pablo II, Saludo de Juan Pablo II a los Pavonianos, Audiencia General - Lunes 15 de abril de 2002, Aula Paolo VI. 
saw that the great need of every man, at all times, is love. He also saw how much personal suffering and how much social unrest arise precisely from the lack of love. That is why he dedicated himself to orphans and then to deaf people. Therefore, in the search for the actuality of his charism, attention must focus more on his intention and attitudes than on specific actions (although some of these actions remain valid and useful today).

In addition, the Preventive System is current because Pavonians continue to be concerned with keeping the charism current through their educational centres and youth pastoral activities internationally, and different Pavoni researchers are concerned with presenting the Preventive System in contemporary language ${ }^{45}$.

When the Church recognised the sanctity of Pavoni, he became part of the spiritual heritage of all Christendom. His heritage must be proposed again today, with creative fidelity, in the returning season of the educational emergency.

\section{References}

Battista, Giovanni. "Presentazione". In AA.VV, Il progetto educativo pavoniano, 3-6. Milano (Italia): Congregazione Religiosa dei Figli di Maria Immacolata. Pavoniani. Provincia Italiana, 2010. Recuperado de: http://www.fassicomo.it/ file_db/fassicomo.it_1297618930.PDF

Bertoldi, Giuliano. L'esperienza apostólica di Lodovico Pavoni. Milano: Áncora, 1997.

Bosco, Teresio. Lodovico Pavoni per i giovani a tempo pieno. Milano: Áncora, 2002. Braido, Pietro. Breve Storia del "Sistema Preventivo". Roma: Librería Ateneo Salesiano, 1993.

Cantú, Roberto. “'Le Scuole delle Arti' di Lodovico Pavoni e l'instruzione professionale a Brescia". In AA.VV, Lodovico Pavoni, -un fondatore e la sua città-, 2000. Atti del Convegno di studi di Brescia 27 marzo 1999.

45 Bertoldi, L'esperienza; Gallliga, "Il metodo", 77-93; Julian García-Velasco, Ludovico Pavoni - Una experiencia pedagógica (Tesis de laurea en Pedagogía, Universidad Pontificia de Salamanca, 1984); Pietro Lombardi, Lodovico Pavoni educatore ed orientatore professionale (Tesi di Diploma presso la Scuola Superiore per Consiglieri di Orientamento Scolastico e Professionale di Verona, 1971); Franco Salomoni, Amore e lavoro nell'azione educativa e nell'opera pedagógica di Lodovico Pavoni (Tesi di Bacellierato nella Facoltá Teologica dell'Italia settentrionale, Venegono Inferiore, 1977). 
Ciardi, Fabio. "Los jóvenes y la pedagogía de los santos". Unidad y Carismas 32 (1999): 21-27.

Congregazione Religiosa dei Figli di Maria Immacolata - Pavoniani. La Regola di Vita. Costituzione. Direttorio. Brescia: Grafiche Pavoniane Artigianelli, 1996. Constituciones de la Congregación Religiosa de los Hijos de María. Brescia: Tipografía Episcopal, 1847; Milán, 1970.

Facco, Giannina. Lodovico Pavoni. Così si fece prossimo. Milano: Áncora, 1987.

Folena, Humberto. Con manos de padre. Beato Ludovico Pavoni. Barcelona: Claret, 2003.

Gallliga, Aurelio. "Il metodo educativo di Lodovico Pavoni”. In AA.VV, Il progetto educativo pavoniano, 77-93. Milano (Italia): Congregazione Religiosa dei Figli di Maria Immacolata. Pavoniani. Provincia Italiana, 2010. Recuperado de: http:/www.fassicomo.it/file_db/fassicomo.it_1297618930.PDF2010.

García-Velasco, Julian. Ludovico Pavoni - Una experiencia pedagógica. Tesis de licenciatura en Pedagogía. Universidad Pontificia de Salamanca, 1984.

Juan Pablo II (2002). Saludo de Juan Pablo II a los Pavonianos. Audiencia General Lunes 15 de abril de 2002. Aula Paolo VI.

Lemoyne, Giovanni Battista. Memorie biografiche di Don Giovanni Bosco. Vol. IV. 1904.

Lettere di Lodovico Pavoni a Domenico Guccini, ed. Giuseppe Rossi. Milano: Congregazione dei Figli di Maria Immacolata (Pavoniani), 1984.

Lombardi, Pietro. Lodovico Pavoni educatore ed orientatore professionale. Tesi di Diploma presso la Scuola Superiore per Consiglieri di Orientamento Scolastico e Professionale di Verona. 1971.

Lodovico Pavoni visto da vicino - Il "Processo informativo" per la beatificazione e canonizzazione - Brescia 1908-1912, ed. Giuseppe Rossi. Milano: Congregazione dei Figli di Maria Immacolata (Pavoniani), 1995.

Rodríguez-Sáez, José Luis. "Ludovico Pavoni: un padre para los jóvenes". Unidad y Carismas 32 (1999): 28-30.

Raccolta ufficiale di documenti e di memorie d'archivio. Vol. I, Brescia, 1947; vol. II, Brescia, 1958; vol. III, Brescia, 1960.

Salomoni, Franco. Amore e lavoro nell'azione educativa e nell'opera pedagógica di Lodovico Pavoni. Tesi di Bacellierato nella Facoltá Teologica dell'Italia settentrionale, Venegono Inferiore. 1977.

Valentini, Eugenio. "La salesianità di Don Bosco". Rivista di pedagogía e scienze religiose 1 (1967): 3-47.

Valli, Aldo Maria. La creatividad del amor. San Ludovico Pavoni. Milán: Áncora Editrice, 2016. 
